\title{
HUBUNGAN PEMAHAMAN KONSEP IKATAN KIMIA DENGAN HASIL BELAJAR KIMIA SISWA PADA MATERI LARUTAN ELEKTROLIT
}

\author{
Nadilla Islamika $^{1}$, Nurlaili ${ }^{2}$, Pintaka Kusumaningtyas ${ }^{3}$ \\ Program Studi Sarjana Pendidikan Kimia, Universitas Mulawarman ${ }^{1,2,3}$ \\ Program Studi Magister Manajemen Pendidikan, Universitas Mulawarman ${ }^{2}$ \\ Program Studi Magister Pendidikan Kimia, Universitas Mulawarman ${ }^{3}$ \\ Email: pintaka@fkip.unmul.ac.id ${ }^{3}$
}

\begin{abstract}
Abstrak
Penelitian ini bertujuan untuk mengukur hubungan signifikan antara pemahaman konsep ikatan kimia dengan hasil belajar kimia siswa pada materi larutan elektrolit. Penelitian ini adalah penelitian korelasional. Populasi dalam penelitian ini adalah seluruh siswa kelas X SMAS Nabil Husein Samarinda tahun ajaran 2018/2019 yang berjumlah 60 siswa. Sampel dalam penelitian ini berjumlah 40 siswa, yang diambil menggunakan teknik simple random sampling. Teknik pengumpulan data dalam penelitian ini menggunakan teknik tes, yaitu tes pemahaman konsep siswa dan tes evaluasi hasil belajar. Data dianalisis menggunakan uji linier regresi, uji korelasi product moment pearson dan uji hipotesis berupa uji $t$. Berdasarkan analisis data, diperoleh hasil bahwa ada hubungan signifikan antara pemahaman konsep ikatan kimia siswa dengan hasil belajar kimia siswa pada pokok bahasan larutan elektrolit, yang ditunjukkan dengan nilai korelasi sebesar 0,410 dengan interpretasi koefisien korelasi sedang dan nilai signifikansi uji $t(0,009<0,05)$.
\end{abstract}

Kata Kunci : pemahaman konsep, ikatan kimia, hasil belajar kimia, larutan elektrolit

\begin{abstract}
This study aims to measure the significant correlation between the conceptual understandings of chemical bond with student chemistry learning outcomes in electrolyte solution material. This research is correlational research. The population in this study were all students of class $X$ Nabil Husein Samarinda in the academic year of 2018/2019 with the amount of 60 students. The sample in this study was 40 students, taken using simple random sampling technique. Data collection techniques in this study were test techniques, namely the students' understanding of concept tests and learning outcomes tests. The data were analyzed using linear regression test, Pearson product moment correlation test and hypothesis testing in the form of t test. Based on data analysis, the results showed that there was a significant correlation between students's conceptual understanding of chemical bond with students' chemistry learning outcomes on the subject of electrolyte solution, which was indicated by a correlation value of 0.410 with an interpretation of the correlation coefficient being moderate and the significance value of the test $(0.009<0.05)$.
\end{abstract}

Key Words : conceptual understanding, chemical bonds, chemical learning outcomes, electrolyte solutions

\section{PENDAHULUAN}

Ilmu kimia sebagai bagian dari sains diperoleh dan dikembangkan berdasarkan percobaan untuk mencari jawaban atas pertanyaan apa, mengapa dan bagaimana gejala-gejala alam yang erat kaitannya dengan kehidupan sehari-hari dapat terjadi. Gejala alam yang dimaksud berkaitan dengan segala sesuatu tentang zat yang meliputi komposisi, struktur, sifat, transformasi, dinamika dan energetika zat
[1]-[3]. Mempelajari ilmu kimia berarti mempelajari konsep-konsep dan faktafakta yang bersifat abstrak. Fenomena yang ada dalam ilmu kimia itu bisa dilihat secara langsung menggunakan indera penglihatan, namun gejala-gejala yang terjadi pada materi dan struktur pada ilmu kimia tidak dapat dilihat secara langsung oleh indera penglihatan. Dalam pelajaran kimia, materi tentang konsep-konsep yang dipelajari saling berkaitan satu sama lain 
dan harus disampaikan secara runtut. Ketika konsep dasar tidak dipahami oleh siswa, maka siswa akan kesulitan memahami konsep kimia pada materi selanjutnya. Oleh karena itu, penguatan konsep dasar itu sangat penting untuk dapat memudahkan siswa memahami materi-materi kimia yang berkaitan dengan konsep tersebut.

Selama ini, guru masih banyak yang menjelaskan konsep-konsep kimia tanpa mengaitkan dengan konsep dasar yang telah dipelajari sebelumnya. Guru hanya menggunakan metode ceramah yang hanya terpaku pada buku teks. Dalam proses belajar mengajar di SMAS Nabil Husein, siswa tidak diwajibkan untuk memiliki buku teks pelajaran kimia sehingga siswa merasa tidak perlu mempunyai referensi tambahan selain yang diajarkan oleh guru di kelas. Oleh karena itu, siswa semakin sulit memahami konsep kimia yang diajarkan oleh guru, sehingga menyebabkan hasil belajar kimia siswa menjadi kurang maksimal [4].

Pemahaman terhadap suatu konsep akan lebih baik jika materi dikaitkan dengan konsep-konsep dasar yang telah dipelajari sebelumnya. Pemahaman adalah suatu kemampuan seseorang dalam mengartikan, menafsirkan, menerjemahkan, atau menyatakan sesuatu dengan caranya sendiri tentang pengetahuan yang pernah diterimanya [5]. Pemahaman konsep yang kuat sangat penting dalam menentukan hasil belajar kimia siswa. Oleh karena itu, penelitian ini bertujuan untuk mengukur hubungan antara pemahaman konsep kimia siswa dengan hasil belajar kimia siswa pada materi Larutan Elektrolit.

\section{METODE}

Penelitian ini menggunakan metode korelasional dan expost facto. Variabel dalam penelitian ini adalah pemahaman konsep ikatan kimia siswa $(X)$ dan hasil belajar kimia siswa $(Y)$. Adapun bentuk rancangan penelitiannya dapat digambarkan sebagai berikut.

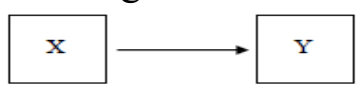

\section{Gambar 1. Rancangan Penelitian}

Keterangan:

$X$ : pemahaman konsep

$Y$ : hasil belajar kimia

Penelitian ini dilaksanakan di SMA Nabil Husein Samarinda pada tahun pelajaran 2018/2019. Populasi dalam penelitian ini adalah seluruh siswa kelas X SMA Nabil Husein Samarinda yang berjumlah 60 siswa. Sampel diambil dengan teknik Simple Random Sampling. Variabel yang diukur adalah variabel bebas berupa pemahaman konsep dan variabel terikat berupa hasil belajar kimia siswa pada akhir pembelajaran.

Teknik pengumpulan data dilakukan dengan teknik tes, yaitu tes pemahaman konsep siswa dan tes evaluasi hasil belajar siswa pada pokok bahasan larutan elektrolit dan non elektrolit. Indikator yang digunakan untuk mengukur pemahaman konsep ikatan kimia siswa terdiri atas indikator translasi, interpretasi dan ekstrapolasi. Sementara indikator hasil belajar kimia siswa disajikan pada Tabel 1.

Tabel 1. Indikator dan Item Tes Hasil Belajar Kimia Siswa

\begin{tabular}{lc}
\hline \multicolumn{1}{c}{ Indikator Kompetensi Dasar } & $\begin{array}{c}\text { Jumlah } \\
\text { butir soal }\end{array}$ \\
\hline $\begin{array}{l}\text { Menjelaskan pengertian larutan } \\
\text { elektrolit dan non elektrolit }\end{array}$ & 1 \\
$\begin{array}{l}\text { Menyebutkan ciri-ciri larutan elektrolit } \\
\text { dan non elektrolit }\end{array}$ & 7 \\
$\begin{array}{l}\text { Mengetahui senyawa-senyawa } \\
\text { pembentuk larutan elektrolit }\end{array}$ & 4 \\
$\begin{array}{l}\text { Menuliskan persamaan reaksi ionisasi } \\
\text { Menjelaskan arah aliran elektron dalam } \\
\text { menghantarkan arus listrik }\end{array}$ & 2 \\
$\begin{array}{l}\text { Membedakan istilah disosiasi dan } \\
\text { ionisasi } \\
\text { Menentukan derajat ionisasi suatu } \\
\text { larutan }\end{array}$ & 1 \\
\hline
\end{tabular}


Skor hasil tes pemahaman konsep ikatan kimia siswa diinterpretasikan menurut kriteria dalam Tabel 2, sedangkan skor tes hasil belajar kimia siswa diinterpretasikan menurut kriteria dalam Tabel 3.

Tabel 2. Kriteria Interpretasi Level Pemahaman Konsep Siswa

\begin{tabular}{cc}
\hline Rentang Skor & Kriteria \\
\hline $0-20$ & Sangat Kurang \\
$21-40$ & Kurang \\
$41-60$ & Cukup \\
$61-80$ & Baik \\
$81-100$ & Sangat Baik \\
\hline & Sumber: $[6]$
\end{tabular}

Tabel 3. Kriteria Interpretasi Hasil Belajar Kimia Siswa

\begin{tabular}{cc}
\hline Rentang Skor & Kriteria \\
\hline $0-40$ & Sangat Kurang \\
$41-60$ & Kurang \\
$61-70$ & Cukup \\
$71-80$ & Baik \\
$81-100$ & Sangat Baik \\
\hline & Sumber: [6]
\end{tabular}

Teknik analisis data yang digunakan terdiri atas uji linier regresi, uji korelasi product moment Pearson dan uji $t$. Data dianalisis menggunakan SPSS versi 16.0. Adapun hipotesis dalam penelitian ini adalah:

$H_{0}$ : tidak terdapat hubungan yang positif dan signifikan antara pemahaman konsep ikatan kimia dengan hasil belajar kimia siswa pada pokok bahasan larutan elektrolit.

$H_{a}$ : terdapat hubungan yang positif dan signifikan antara pemahaman konsep ikatan kimia dengan hasil belajar kimia siswa pada pokok bahasan larutan elektrolit.

\section{HASIL DAN PEMBAHASAN}

Data hasil tes pemahaman konsep ikatan kimia siswa dideskripsikan dalam bentuk persentase distribusi berdasarkan jumlah siswa yang mencapai level pemahaman konsep pada setiap kriteria, sebagaimana dalam Gambar 1. Level pemahaman konsep ikatan kimia siswa paling besar berada pada kriteria cukup, yaitu sebesar
$40 \%$, sedangkan level pemahaman konsep ikatan kimia siswa pada berada pada kriteria kurang paling sedikit, yaitu sebesar $15 \%$. Sementara sebanyak $45 \%$ siswa telah berada pada level pemahaman konsep ikatan kimia dengan kriteria baik $(22,5 \%)$ dan sangat baik $(22,5 \%)$.

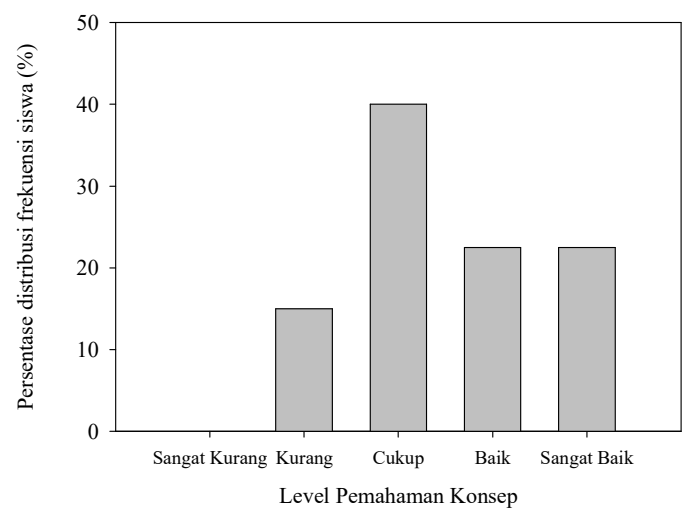

\section{Gambar 2. Persentase Distribusi Level Pemahaman Konsep Ikatan Kimia Siswa}

Data hasil belajar kimia siswa pada pokok bahasan larutan elektrolit juga dideskripsikan dalam bentuk persentase distribusi sebagaimana dalam Gambar 3 berikut.

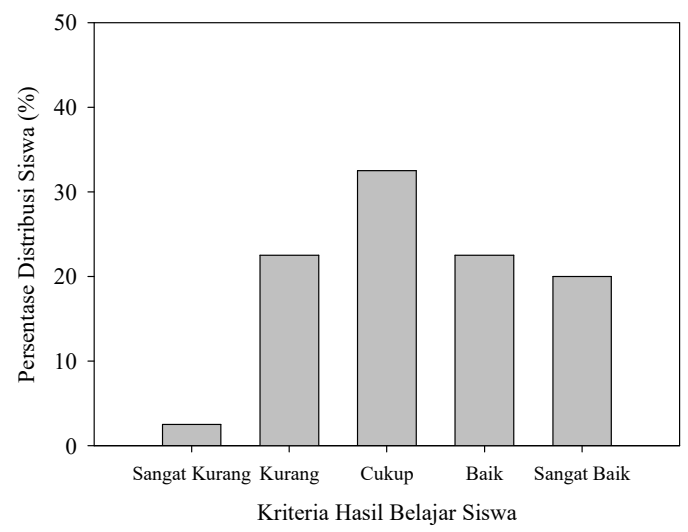

Gambar 3. Persentase Distribusi Kriteria Hasil Belajar Kimia Siswa

Persentase hasil belajar kimia siswa yang paling banyak berada pada kriteria cukup, yaitu sebesar $32,5 \%$, sedangkan persentase yang paling sedikit berada pada kriteria sangat kurang, yaitu sebesar $15 \%$. Sementara sebanyak $42,5 \%$ siswa telah 
berada pada level pemahaman konsep ikatan kimia dengan kriteria baik $(22,5 \%)$ dan sangat baik (20\%), sedangkan sisanya sebanyak $22,5 \%$ masih berada pada kriteria kurang. Rata-rata nilai hasil belajar kimia siswa adalah 69 , yang berada pada kriteria cukup. Namun jika dilihat dari nilai Kriteria Ketuntasan Minimal (KKM) yang ditetapkan oleh sekolah, yaitu 70, maka nilai rata-rata hasil belajar kimia siswa tersebut masih berada di bawah nilai
KKM, sebab hanya sebanyak 50\% siswa dari 40 orang siswa yang mampu mencapai ketuntasan belajar.

Hubungan antara kedua variabel dapat dilihat dari distribusi frekuensi level pemahaman konsep yang dikorelasikan dengan kriteria hasil belajar kimia siswa sebagaimana dalam Tabel 4.

Tabel 4. Distribusi Frekuensi Hubungan Pemahaman Konsep Ikatan Kimia dan Hasil Belajar Kimia

\begin{tabular}{|c|c|c|c|}
\hline $\begin{array}{c}\text { Kriteria } \\
\text { (Pemahaman Konsep) }\end{array}$ & $\begin{array}{c}\text { Jumlah Siswa } \\
\text { (Pemahaman Konsep) }\end{array}$ & $\begin{array}{c}\text { Kriteria } \\
\text { (Hasil Belajar) } \\
\end{array}$ & $\begin{array}{l}\text { Jumlah Siswa } \\
\text { (Hasil Belajar) }\end{array}$ \\
\hline \multirow{5}{*}{ Sangat Kurang } & \multirow{5}{*}{0} & $\begin{array}{l}\text { Sangat } \\
\text { Kurang }\end{array}$ & 0 \\
\hline & & Kurang & 0 \\
\hline & & Cukup & 0 \\
\hline & & Baik & 0 \\
\hline & & Sangat Baik & 0 \\
\hline \multirow{5}{*}{ Kurang } & \multirow{5}{*}{6} & $\begin{array}{l}\text { Sangat } \\
\text { Kurang }\end{array}$ & 1 \\
\hline & & Kurang & 5 \\
\hline & & Cukup & 0 \\
\hline & & Baik & 0 \\
\hline & & Sangat Baik & 0 \\
\hline \multirow{5}{*}{ Cukup } & \multirow{5}{*}{16} & $\begin{array}{l}\text { Sangat } \\
\text { Kurang }\end{array}$ & 0 \\
\hline & & Kurang & 4 \\
\hline & & Cukup & 10 \\
\hline & & Baik & 2 \\
\hline & & Sangat Baik & 0 \\
\hline \multirow{5}{*}{ Baik } & \multirow{5}{*}{9} & $\begin{array}{l}\text { Sangat } \\
\text { Kurang }\end{array}$ & 0 \\
\hline & & Kurang & 0 \\
\hline & & Cukup & 3 \\
\hline & & Baik & 5 \\
\hline & & Sangat Baik & 1 \\
\hline \multirow{5}{*}{ Sangat Baik } & \multirow{5}{*}{9} & $\begin{array}{l}\text { Sangat } \\
\text { Kurang }\end{array}$ & 0 \\
\hline & & Kurang & 0 \\
\hline & & Cukup & 0 \\
\hline & & Baik & 2 \\
\hline & & Sangat Baik & 7 \\
\hline
\end{tabular}

Berdasarkan Tabel 4 dapat diketahui bahwa sebanyak $78 \%$ siswa dengan kriteria pemahaman konsep sangat baik juga memperoleh hasil belajar kimia pada kriteria sangat baik dan sisanya pada kriteria baik. Demikian pula siswa dengan kriteria pemahaman konsep kurang, 83\% di antaranya memperoleh hasil belajar kimia pada kriteria kurang dan sisanya sangat kurang. Hal ini menunjukkan bahwa terdapat hubungan antara pemahaman konsep ikatan kimia dengan hasil belajar 
kimia siswa pada pokok bahasan larutan elektrolit.

Untuk mengetahui apakah terdapat hubungan yang positif dan signifikan antara pemahaman konsep ikatan kimia $(X)$ dengan hasil belajar kimia pada pokok bahasan larutan elektrolit (Y), maka dilakukan analisis korelasi product moment. Hasil uji linieritas menggunakan uji $F$ menunjukkan bahwa $F_{\text {hitung }}=7,7686$ $>F_{\text {tabel }}=4,08$ dengan nilai signifikansi $0,009(P<0,05)$, yang berarti bahwa data memenuhi kriteria linieritas untuk dilakukan uji korelasi. Hasil uji korelasi product moment menggunakan SPSS 16 disajikan pada Tabel 5 .

Tabel 5. Analisis Korelasi Product Moment Pearson

\begin{tabular}{crrcc}
\hline$R_{X Y}$ & $t_{\text {hitung }}$ & $t_{\text {tabel }}$ & Signifikansi & Ket \\
\hline 0,410 & 2,772 & 1,685 & 0,009 & Positif \\
\hline
\end{tabular}

Hasil analisis menunjukkan bahwa ada hubungan positif antara kedua variabel dengan nilai korelasi $(r)$ sebesar 0,410 (kategori sedang). Besarnya pengaruh pemahaman konsep ikatan kimia terhadap hasil belajar kimia diketahui melalui koefisien determinasi $\left(r^{2}\right)$ yaitu sebesar 0,168 , yang berarti bahwa pemahaman konsep ikatan kimia memiliki pengaruh kontribusi sebesar $16,8 \%$ terhadap hasil belajar kimia siswa pada pokok bahasan larutan elektrolit.

Hasil uji hipotesis (uji $t$ ) menunjukkan bahwa $t_{\text {hitung }}=2,772>t_{\text {tabel }}=1,685$, yang berarti bahwa hubungan kedua variabel adalah signifikan. Ada hubungan positif dan signifikan antara pemahaman konsep dan hasil belajar siswa, yang berarti bahwa siswa dengan pemahaman konsep yang baik akan memperoleh hasil belajar yang baik pula [7], [8]. Hal senada bahwa semakin tinggi pemahaman konsep siswa maka semakin tinggi pula hasil belajar siswa [9].
Adanya hubungan positif dan signifikan antara pemahaman konsep ikatan kimia dengan hasil belajar kimia siswa pada pokok bahasan larutan elektrolit mengindikasikan bahwa pemahaman konsep ikatan kimia ternyata mampu membantu siswa dalam mencapai indikator kompetensi dasar pada pokok bahasan larutan elektrolit yang berjumlah 20 item soal (Tabel 1). Materi ikatan kimia merupakan salah satu konsep dasar inti yang harus dikuasai oleh siswa karena sangat berkaitan dengan konsep-konsep materi kimia yang dipelajari selanjutnya. Konsep tentang pembentukan larutan elektrolit sangat berkaitan dengan konsep tentang bentuk geometri molekul air dan sifat kepolaran air. Kemampuan siswa untuk menghubungkan konsep bentuk geometri dan sifat kepolaran air dengan kemampuan air dalam melarutkan senyawa-senyawa ionik dapat membantu siswa dalam memahami bagaimana larutan elektrolit dapat menghantarkan arus listrik.

Kegagalan sebagian siswa $(50 \%)$ dalam mencapai ketuntasan belajar pada pokok bahasan larutan elektrolit disebabkan karena siswa mengalami miskonsepsi pada konsep ikatan kimia. Penelitian juga menemukan bahwa 50\% siswa mengalami miskonsepsi pada materi ikatan kimia [10]. Miskonsepsi yang sering ditemukan pada materi ikatan kimia adalah kesalahan siswa dalam mempersepsikan senyawa ionik, siswa bingung menentukan geometri molekul berdasarkan distribusi pasangan elektron bebas yang mengelilingi atom pusatnya dan kesalahan siswa dalam memprediksi polaritas molekul [11]. Miskonsepsi ini menyebabkan siswa tidak dapat membedakan larutan elektrolit dan non elektrolit berdasarkan jenis senyawa zat terlarutnya dan tidak mampu menuliskan persamaan reaksi ionisasinya.

Berdasarkan Tabel 4, terdapat beberapa siswa yang memiliki pemahaman konsep 
ikatan kimia pada kriteria cukup, namun mampu memperoleh hasil belajar kimia dengan kriteria baik dan ada siswa yang memiliki pemahaman konsep dengan kriteria baik namun mampu memperoleh hasil belajar dengan kriteria sangat baik. Hal ini menunjukkan bahwa ada faktor lain yang berpengaruh terhadap hasil belajar kimia, di antaranya yaitu siswa hanya membedakan larutan elektrolit dan non elektrolit dengan menghapal ciri-cirinya berdasarkan data hasil uji elektrolit apakah lampu menyala atau ada gelembung, tanpa harus memahami konsep jenis senyawa pembentuknya. Selain itu, ada pula siswa yang memiliki pemahaman konsep dengan kriteria cukup namun memperoleh hasil belajar kimia dengan kriteria kurang. Hal ini mengindikasikan bahwa ada faktor lain yang menghambat keberhasilan siswa dalam mencapai ketuntasan belajar, seperti faktor sekolah dan faktor guru [12]-[14].

Hasil penelitian ini memberikan rekomendasi bahwa guru perlu memberikan penguatan terhadap konsep prasyarat sebelum mengajarkan konsep kimia yang baru agar miskonsepsi siswa terhadap konsep prasayarat dapat direduksi dan hasil belajar kimia pada pokok bahasan yang berkaitan dengan konsep materi prasyarat tersebut dapat ditingkatkan.

\section{SIMPULAN}

Berdasarkan hasil penelitian ini dapat disimpulkan bahwa ada hubungan positif yang signifikan antara pemahaman konsep ikatan kimia dan hasil belajar kimia siswa pada pokok bahasan larutan elektrolit dengan kategori korelasi sedang $(r=$ 0,410 ) dan besar kontribusi sebesar $16,8 \%$.

\section{DAFTAR PUSTAKA}

[1] Trianto. Model Pembelajaran Terpadu. Surabaya: Bumi Aksara, 2010.

[2] N. Fadliawati. "Perkembangan
Konsep Pembelajaran tentang Struktur Atom dari SMA Hingga Perguruan Tinggi". Universitas Pendidikan Indonesia, 2011.

[3] Kemendikbud. Silabus Mata Pelajaran Kimia Sekolah Menengah Atas/Madrasah Aliyah (SMA/MA). Jakarta: Kemendikbud, 2016.

[4] R. F. Herawati, S. Mulyani, dan T. Redjeki. "Pembelajaran Kimia Berbasis Multiple Representasi Ditinjau dari Kemampuan Awal terhadap Prestasi Belajar Laju Reaksi Siswa SMP N 1 Karanganyar tahun 2011/2012". Jurnal Pendidikan Kimia, vol. 2, no. 2, pp. 38-43, 2013.

[5] S. S. Arif. Media Pendidikan: Pengertian, Pengembangan, dan Pemanfaatannya. Jakarta: PT. Raja Grafindo Persada, 2012.

[6] S. M. Masyhud. Metode Penelitian Pendidikan. Jember: Lembaga Pengembangan Manajemen dan Profesi Pendidikan, 2013.

[7] L. N. K. Siregar. "Korelasi Pemahaman Konsep Aljabar dengan Hasil Belajar Matematika”. NIZHAMIYAH, vol. VII, no.1, pp. 22-33, 2017.

[8] S. Rozikin, H. Amir, dan S. Rohiat. "Hubungan Minat Belajar Siswa dengan Prestasi Belajar Siswa pada Mata Pelajaran Kimia di SMA Negeri 1 Tebat Karai dan SMA Negeri 1 Kabupaten Kepahiang". ALOTROP, vol. 2 , no. 1 , pp. $78-81$, 2018.

[9] E. Istikomah. "The relationship between conceptual understanding and student learning outcomes through the use of geometers Sketchpad software". IOP Conf. Ser. 1157 , 2019, doi: 10.1088/17426596/1157/4/042070.

[10] S. Fadillah dan D. Salirawati, "Analysis of Misconceptions of Chemical Bonding Among Tenth Grade Senior High School Students 
Using a Two-Tier Test". AIP Conf. Proc. 2021, 080002-1-080002-7, 2018, doi: 10.1063/1.5062821.

[11] J. R. B. Pérez, M. E. B. Pérez, M. L. Calatayud, R. Garcia-Lopera, J. V. S. Montesions, and E. T. Gil., "Student's Misconceptions on Chemical Bonding: A Comparative Study between High School and First Year University Students". Asian Journal of Education and eLearning, vol. 05, issue. 01, pp. 1-15, 2017.

[12] A. M. Oginni, V. Y. Awobodu, M. O. Alaka, and S. O. Saibu. "School Factors as Correlates of Students' Achievement in Chemistry".
International Journal for CrossDisciplinary Subject Education (IJCDSE), vol. 3, issue 3, pp. 15161523, 2013.

[13] D. Cheung. "Student Attitudes toward Chemistry Lessons to Enhance Teaching in the Secondary School". Educ. quim, vol. 22, no. 2, pp. 117-122, 2011.

[14] K. Osman and N. S. Sukor, "Conceptual Understanding in Secondary School Chemistry: A Discussion of the Difficulties Experienced by Students". Am. J. Appl. Sci., vol. 10, no. 5, pp. 433441, 2013. 